\title{
Burrow morphology and behavior of the mud shrimp Upogebia omissa (Decapoda: Thalassinidea: Upogebiidae)
}

\author{
Vânia Rodrigues Coelho' ${ }^{1,}$, Roland Arthur Cooper ${ }^{2}$, Sérgio de Almeida Rodrigues ${ }^{3}$ \\ ${ }^{1}$ Departamento de Zoologia, Instituto de Biociências, Universidade de São Paulo, São Paulo, SP, CP: 11461, CEP: 05422-970, Brazil \\ ${ }^{2}$ National Institutes of Health, Bethesda, Maryland 20892, USA \\ ${ }^{3}$ Departamento de Ecologia Geral, Instituto de Biociências, Universidade de São Paulo, São Paulo, SP, CP: 11461, \\ CEP: 05422-970, Brazil
}

\begin{abstract}
The burrow morphology, burrowing behavior and feeding mechanisms of the thalassinidean shrimp Upogebia omissa were studied. Twenty burrow casts were made in situ with epoxy resin, and an overall ' $\mathrm{Y}$ ' shape was most frequently observed. Several burrows consisted of a single, oblique tunnel; burrow diameter was positively correlated with burrow length, maximum depth and distance between openings. Additionally, burrow length was positively associated with maximum depth, indicating that as burrow length increased burrow depth increased; i.e. burrows spread vertically rather than horizontally. Total sediment displacement by the burrows accounted for $2.6 \%$ of sediment to a depth of $30 \mathrm{~cm}$. The sediment-water interface increased by $290 \%$ in areas containing burrows compared to areas without burrows. Solitary adults were trapped in 15 casts. Three casts were interconnected, but each burrow contained only 1 shrimp. Regression analysis revealed shrimp length to be positively correlated with burrow diameter and area. In aquaria, $U$. omissa displayed a dual feeding behavior: the shrimp filtered suspended particles, and also fed directly on the sediment. Filter-feeding occurred mainly within U-shaped tunnels, while deposit-feeding was observed in association with the oblique tunnels of the burrow. Although filter-feeding has been considered as the main trophic mode in upogebiids, we present evidence that $U$. omissa may have a more pronounced deposit-feeding behavior than described for other species of this group. Based on our findings, we suggest that current models on the functional morphology of burrows in relation to feeding should be used cautiously in inferring the trophic behavior of these shrimp.
\end{abstract}

KEY WORDS: Shrimp $\cdot$ Burrow $\cdot$ Feeding $\cdot$ Upogebia $\cdot$ Decapoda $\cdot$ Thalassinidea

\section{INTRODUCTION}

Thalassinideans are the most extraordinary and proficient diggers among burrowing decapod crustaceans (Rodrigues \& Hödl 1990). Aside from a brief pelagic larval stage, most species reside within the burrow for the duration of their lives (Griffis \& Suchanek 1991). They depend on burrows for shelter, protection from predators, feeding and reproduction. Thalassinideans are usually abundant in intertidal and subtidal soft

- Present address: Columbia University, Biosphere 2. Center, 32540 Biosphere Rd, Oracle, Arizona 85623، USA.

E-mail: vcoelho@bio2.edu bottoms (Dworschak 1987a, Swinbanks \& Luternauer 1987, Dworschak \& Pervesler 1988, Griffis \& Chavez 1988, Lemaitre \& Rodrigues 1991). As a result of increased oxygenation and turnover of the substrate through burrowing and feeding activities, they significantly influence sediment characteristics as well as composition and density of other organisms within the benthic community (Pemberton et al. 1976, Brenchley 1981, Posey 1986, Branch \& Pringle 1987, Dobbs \& Guckert 1988, Posey et al. 1991, Ziebis et al. 1996).

Because of their cryptic lifestyle, the natural history of these organisms has not been well investigated. The difficulties in capturing specimens, some of which can burrow more than $2 \mathrm{~m}$ deep (Pemberton et al. 1976), 
and observing them in the laboratory are such that many aspects of their biology are poorly understood or unknown. Nonetheless, since the advent of the resincasting technique (Shinn 1968), the study of thalassinidean burrow morphology has greatly improved (Pemberton et al. 1976, Dworschak 1983, Nash et al. 1984, Atkinson \& Nash 1990, Nickell \& Atkinson 1995, Ziebis et al. 1996). This technique provides nearly perfect replicas of burrows in situ that can be studied in detail in the laboratory.

Filter- and deposit-feeding are the 2 main trophic mechanisms described for thalassinideans. Members of this group may specialize in one of these mechanisms, while others utilize both feeding modes (MacGinitie 1930, Scott et al. 1988, Rodrigues \& Hödl 1990, Nickell \& Atkinson 1995). An elaborate modification of deposit-feeding, known as 'gardening' (Hylleberg 1975, Dworschak 1987b), has also been described, whereby animals increase the quantity of organic matter in the sediment by burying plant fragments or other debris in their burrow walls and later grazing on the enriched substrate (Rodrigues 1966, Dworschak 1987b, Griffis \& Chavez 1988). Upogebiids have been considered as primarily filter-feeders (MacGinitie 1930 . Dworschak 1987b, Scott et al, 1988, Nickell \& Atkinson 1995), although certain species are also capable of deposit-feeding (Dworschak 1987b, Nickell \& Atkinson 1995).

Recently, models have been proposed for thalassinideans that relate burrow architecture to the trophic mode of the inhabitant (Griffis \& Suchanek 1991, Nickell \& Atkinson 1995). The filter-feeding behavior of upogebiid shrimps appears to be primarily associated with the U-shaped tunnel frequently observed in their burrows (Ott et al. 1976, Dworschak

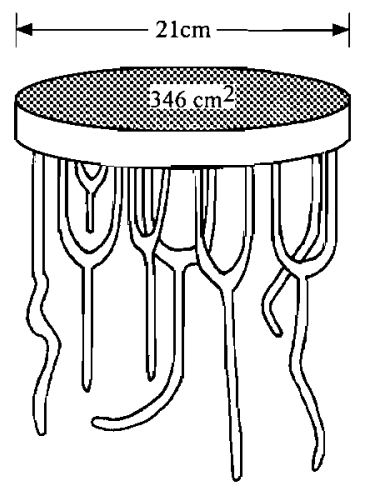

Fig. 1. Upogebia omissa. Representative resin cast of burrows obtained in situ, indicating dimensions of sediment enclosed by frame. Cast was obtained by pouring resin into a cylindrical frame which had been buried in the sediment, enclosing several burrow openings. After hardening, the cast was removed, producing a replica of the burrows 1987b, Nickell \& Atkinson 1995). However, the relationship between deposit-feeding and burrow architecture is not well-documented in this family.

The present study examines the burrow morphology and the feeding mechanisms of a species of mud shrimp Upogebia omissa that occurs in high densities along the southeastern Brazilian coast. Despite the wide distribution of this species, from the Atlantic coast of Florida, USA, to Santa Catarina, Brazil (Williams 1993), and its potential importance in benthic communities, there have been no previous studies on this species, aside from that providing its original description (Gomes Corrêa 1968). We analyze the functional morphology of the burrows in relation to trophic modes and discuss the validity of the current models. Additionally, burrowing behavior is described and compared to that of other species in this family.

\section{METHODS}

Study site. The studied population of Upogebia omissa was located in the shallow subtidal areas of Praia do Segredo Bay, São Sebastião, São Paulo, Brazil $\left(23^{\circ} 49^{\prime} 41^{\prime \prime} \mathrm{S}, 45^{\circ} 25^{\prime} 22^{\prime \prime} \mathrm{W}\right)$. A map of the study site can be found in Rodrigues \& Rocha (1993). The sediment at this locality consisted of a mixture of fine sand, gravel and shell fragments. Casts were made during March 1994, from an area with a density of $\sim 200$ burrow openings $\mathrm{m}^{-2}$. $U$. omissa was the only species of thalassinidean observed in this area. Field studies were conducted with the aid of SCUBA.

Burrow casts. Burrow casts were made in situ using epoxy resin (Araldit MY 257: HY 830, 1.67: $1 \mathrm{w} / \mathrm{w}$; CIBAGIEGE, São Paulo, SP, Brazil), based on the method of Dworschak (1983). A plastic cylindrical frame $30 \mathrm{~cm}$ high by $21 \mathrm{~cm}$ in diameter was partially buried in the sediment surrounding several burrow openings. The surface area of sediment enclosed within the frame was $346 \mathrm{~cm}^{2}$. Resin was poured into the frame, covering the burrow openings to a level just below the top of the frame and sufficient to fill the burrows. This procedure was repeated at a location with a similar density of openings $\sim 6 \mathrm{~m}$ from the first site. After 4 or $5 \mathrm{~d}$, the hardened casts were carefully removed from the sediment. The resin, with a viscosity and density greater than water, inundated the burrows, thus supplying a replicate of the entire structure (Figs. $1 \& 2$ ).

Average burrow diameter was measured from the hardened casts with a sliding caliper; it was recorded several centimeters below the burrow opening, which was representative of the majority of the burrow diameter. Other data recorded include horizontal distance between openings when a single burrow showed more than 1 opening; depth of the U-shaped tunnel; maxi- 

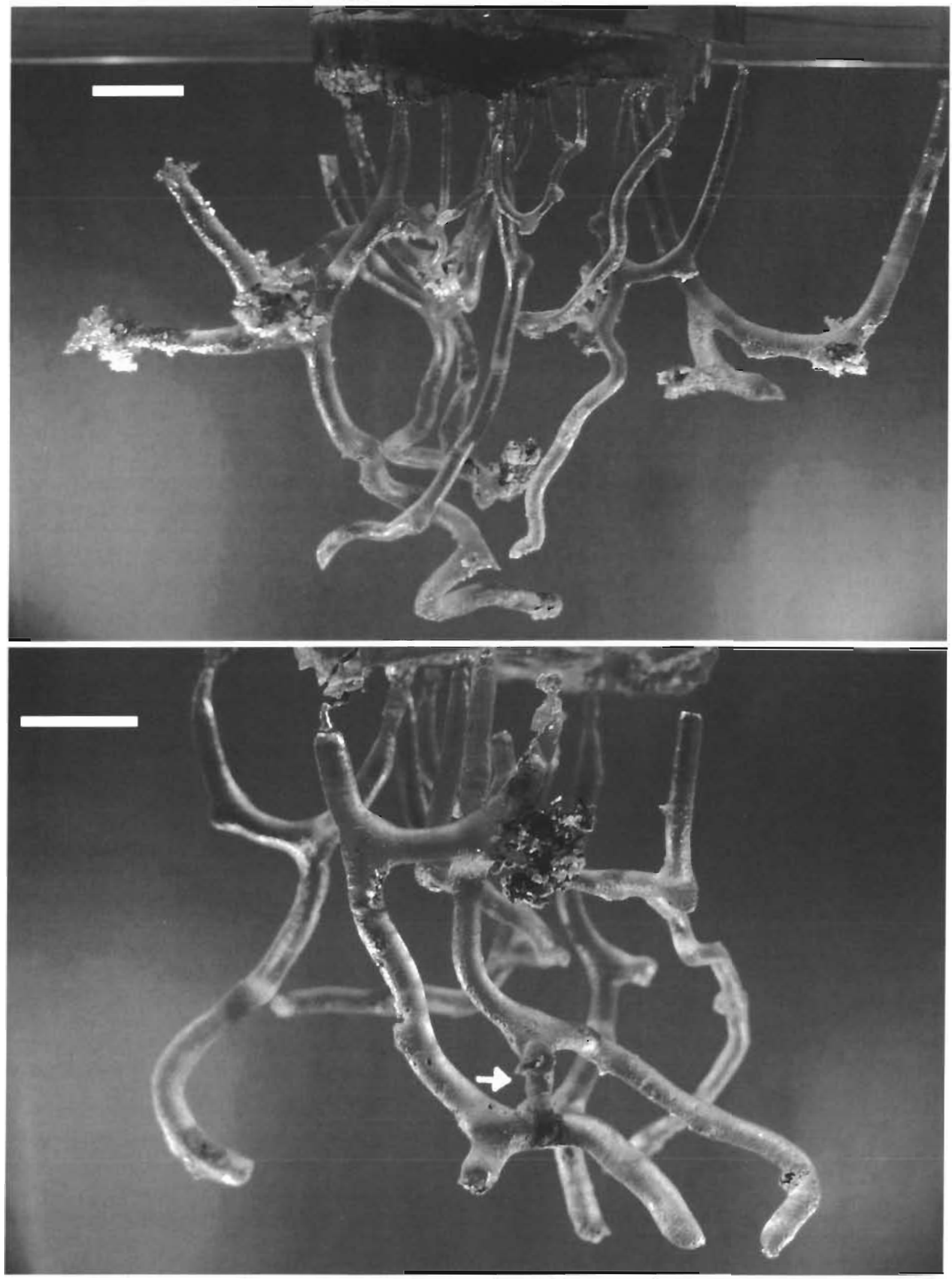

Fig. 2. Upogebia omissa. Burrow casts obtained in situ. (A) Cast from Frame 1, illustrating density and diversity of burrows (B) Cast from Frame 2. Arrow indicates interconnection between 2 burrows. Scale bars $=5 \mathrm{~cm}$ 


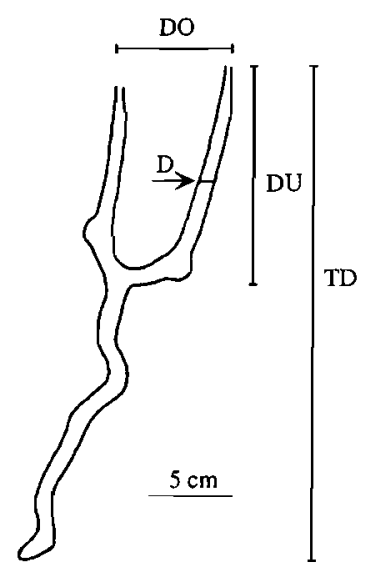

Fig. 3. Upogebia omissa. Representative individual burrow cast indicating dimensions recorded. $\mathrm{D}$ : burrow diameter; DO: distance between openings; DU: depth of U-shaped tunnel; TD: total depth

mum burrow depth total length (recorded with the aid of a string) (Fig. 3). Variation in diameter near openings and chambers was a minor component of the rather uniformly cylindrical casts, allowing the calculation of individual burrow surface area and volume from total length and diameter. Sediment volume (surface area enclosed within the frame multiplied by the depth of the deepest burrow) and total surface area and volume of all burrows found in the enclosures were calculated.

Shrimp. Body length, measured as distance from the tip of the rostrum to the posterior edge of the last abdominal segment (the telson of the shrimp trapped in the casts were curved and thus did not allow more precise measurements) and carapace length (tip of rostrum to posterior edge of the carapace) of all intact shrimp trapped in the casts were recorded with a sliding caliper. Linear regression analyses relating shrimp size with burrow dimensions were performed with the aid of a computer program (STATA, Stata Corporation, College Station, Texas, USA).

Behavioral studies. Specimens of Upogebia omissa were collected from March 1993 to April 1994 from depths ranging from 1 to $10 \mathrm{~m}$ using an air-lift adapted from Bussers et al. (1983). Sixteen live specimens were kept in a modified aquarium, either individually or in groups of 2 or 3, to record feeding and burrowing behavior (MacGinitie 1934, Rodrigues 1983, Rodrigues \& Hödl 1990). The aquarium measured $30 \mathrm{~cm} \times 20 \mathrm{~cm}$ $\times 40 \mathrm{~cm}$ (length $\times$ depth $\times$ height). A resin plate placed within the aquarium created a living space of $\sim 1 \mathrm{~cm}$ in depth, allowing the shrimp and burrows to be observed at all times (Rodrigues \& Hödl 1990). The living space of the aquarium was filled with sediment from the collection site. Shrimp were maintained in fil- tered sea water and fed every second day with a mixture of fine sand and commercial fish food. Observations of the shrimp were made during the daytime and early evening. Changes in burrow morphology were recorded by outlining the burrow shape on the glass wall of the aquarium. The taxonomic nomenclature used throughout this paper for upogebiids follows that of Williams (1993).

\section{RESULTS AND DISCUSSION}

\section{Burrow casts}

To study the burrow morphology of Upogebia omissa, epoxy resin casts were made from 2 sites representing a total bottom area of $692 \mathrm{~cm}^{2}$. Sixteen apparently complete burrow replicates were removed from the sediment after the resin had hardened (Fig. 2). Four other complete burrows from an earlier pilot study of the resin-casting technique were included in this analysis. The burrows were circular in cross-section and often had constricted openings (Fig. 4). No funnel-shaped, or mound-like openings were observed. The most common pattern found in the burrow casts was a U-shaped tunnel followed by a vertical shaft connected to the deepest part of this ' $U$ ', producing an overall ' $Y$ ' format. The predominance of $\mathrm{Y}$-shaped burrows in this study are typical of the Upogebiidae (MacGinitie 1930, Pearse 1945, Frey \& Howard 1975, Ott et al. 1976, Swinbanks \& Murray 1981, Dworschak 1983, 1987b, Scott et al. 1988, Candisani 1994, Candisani et al. 1994, Nickell \& Atkinson 1995, Astall et al. 1997), and some species of the Callianassidae (Swinbanks \& Murray 1981, Griffis \& Chavez 1988, Lemaitre \& Rodrigues 1991).

Although the Y-shaped burrow was the most common pattern observed, variations of this format occurred (Figs. 2A \& 4); for example, some burrows consisted of a single oblique tunnel (Fig. 4C). Some Yshaped burrows contained a loosely spiraled vertical tunnel (Fig. $4 \mathrm{~B}, \mathrm{D}$ ). There often was a roughly spherical enlargement (chamber) in 1 or more of the vertical arms of the $\mathrm{U}$ (Fig. $4 \mathrm{~A}, \mathrm{~B}, \mathrm{E}, \mathrm{F}$ ), and such chambers were also found in other parts of the burrows (Fig. 4C,F). Small side branches, apparently serving as gravel deposits, were observed in several burrows (Fig. 4D,E); these sediment deposits were occasionally found in other burrow locations, including chambers and maintunnel ends (Fig. 4D,E,F).

Of the 20 burrows, 12 had 2 surface openings, usually corresponding to the Y-format of the burrow. Distance between burrow openings ranged from 3.0 to $15.0 \mathrm{~cm}$. The remaining 8 burrows had a single opening at the sediment surface. Burrow diameter ranged from 0.4 to $1.3 \mathrm{~cm}$, depth of the U-shaped tunnel from 3.0 to 
$15.2 \mathrm{~cm}$. The greatest observed total depth was $30 \mathrm{~cm}$, the greatest total length $86 \mathrm{~cm}$. Areas of individual casts ranged from 14.1 to $297.2 \mathrm{~cm}^{2}$, and burrow volume from 1.4 to $81.7 \mathrm{~cm}^{3}$ (Table 1). Linear regression analysis was performed to test for associations between the various burrow measurements (Fig. 5). Burrow diameter was found to be positively associated with burrow length, maximum depth and distance between openings $(p=$ $0.002,0.007$, and 0.018 , respectively). Additionally, burrow length was positively associated with maximum depth $(p=0.002)$, indicating that as burrow length increased, burrow depth increased; i.e. burrows spread vertically rather than horizontally.

Among the Thalassinidea, burrow architecture is usually species-specific, although certain patterns often emerge that may be representative for an entire family or genus. Burrow format has not only a phylogenetic component (Dworschak \& Ott 1993), but may also depend on physical and biological parameters. Variation in burrow shape within different species has been attributed to sediment types, the presence of stones in the substrate, burrow density and content of organic matter (Nash et al. 1984, Griffis \& Chavez 1988, Nickell \& Atkinson 1995, Rowden \& Jones 1995, Astall et al. 1997). Table 2 presents a morphometric comparison of burrows among species of Upogebia.

From the casts of the 2 frames (combined data), total burrow area and volume were calculated as $1988.7 \mathrm{~cm}^{2}$ and $505.2 \mathrm{~cm}^{3}$, respectively. Based on these values, total sediment displaced by the burrows was calculated as $2.6 \%$ of the sediment to a depth of $30 \mathrm{~cm}$ (depth of deepest burrow). This resulted in an increase in the sediment-water interface of $290 \%$ in areas containing burrows compared to areas without burrows. A similar finding was recorded for species of Callianassidae (Dworschak \& Pervesler 1988, Ziebis et al. 1996). Thalassinidean shrimp increase the amount of oxygen in deeper substrate layers through the regular beating of their pleopods, which promotes an incoming current, and by the passive hydrodynamic flow of water past the burrow entrances (Ziebis et al. 1996). This change from anaerobic to aerobic conditions creates a suitable environment for proliferation of the microbial community (Branch \& Pringle 1987, Dobbs \& Guckert 1988 ) as well as for populations of other organisms such as crabs and copepods (MacGinitie 1930, Phillips 1971, Kihara \& Rocha 1993, Alves \& Pezzuto 1998), which apparently live as commensals in the protection of the burrow tunnels. Thalassinideans further affect the composition and abundance of benthic organisms through their bioturbating behavior. The sediment turnover arising from their burrowing and feeding activities can have either a negative or a positive impact on certain benthic species (Brenchley 1981, Posey 1986, Posey et al. 1991).

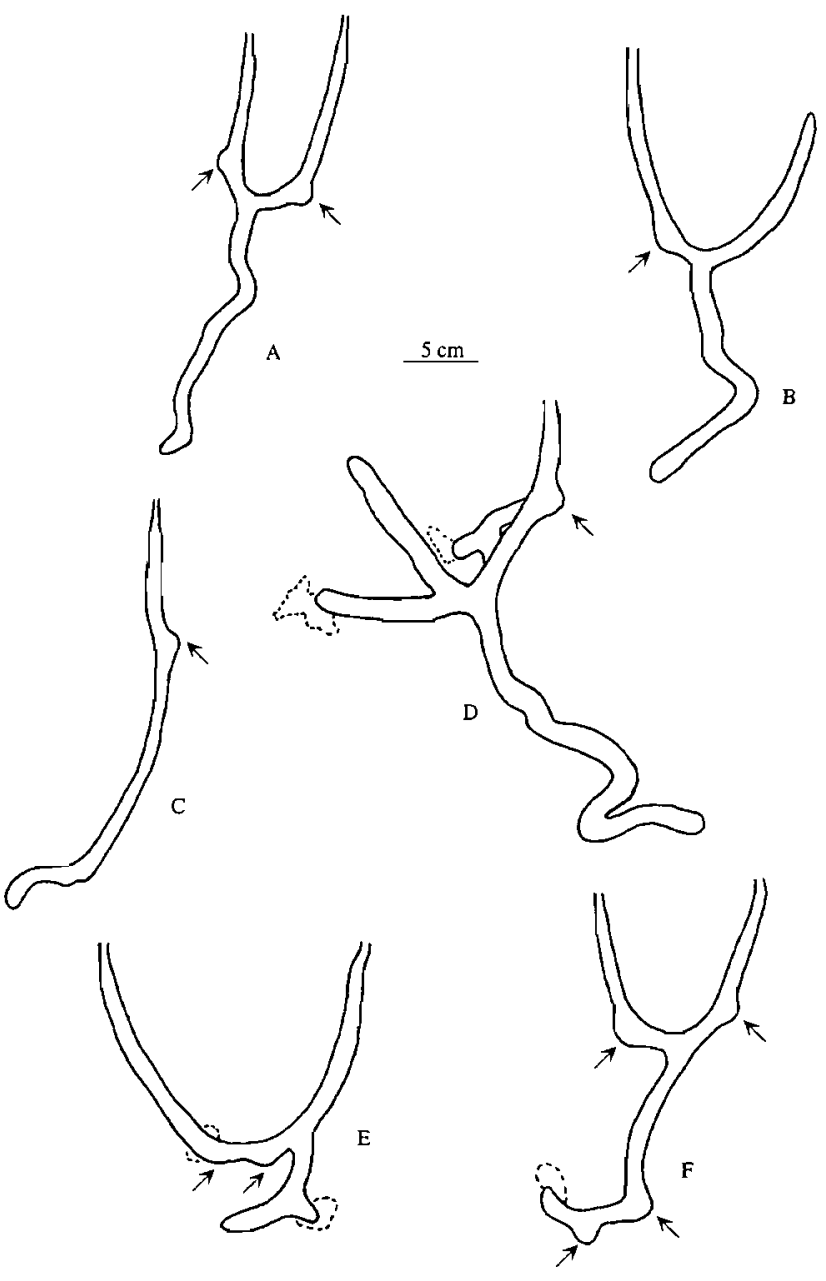

Fig. 4. Upogebia omissa. Burrow morphology drawn from resin casts. Arrows indicate burrow chambers. Dashed lines correspond to areas of gravel deposit. (A,B) Y-shaped burrow with spiraled vertical tunnel, showing chambers in 1 or more of the vertical branches of the U-shaped tunnel. (C) Burrow consisting of single oblique tunnel. (D) Burrow with side branches used as gravel deposits. (E) Y-shaped burrow with chambers in 1 branch of U-tunnel and in vertical tunnel; gravel deposits are present in some chambers. (F) Y-shaped burrow with chambers in both branches of U-tunnel and vertical tunnel, and gravel deposit at the end of the main tunnel

\section{Shrimp}

Individual shrimp were found entrapped within the resin of 15 casts. Two individuals were incomplete, and only partial measurements could be made of these. In accordance with the majority of the Upogebiidae so far studied (Ott et al. 1976, Swinbanks \& Murray 1981, Dworschak 1983, Astall et al. 1997), no casts were observed to contain more than 1 individual. This was expected, since species of this group usually display aggressive intraspecific behavior (Pearse 1945, Ott et al. 1976, Tunberg 1986). Because the shrimp were 
Table 1. Upogebia omissa. Dimensions of burrow casts and trapped shrimp. NO: number of surface openings; DO: distance between surface openings (cm), D: tunnel diameter (cm); DU: depth of the U-shaped tunnel (cm); TD: total depth (cm); L: length $(\mathrm{cm})_{i}$ A: area $\left(\mathrm{cm}^{2}\right)$; V: volume $\left(\mathrm{cm}^{3}\right)_{\text {; }}$ BL: body length of trapped shrimp $(\mathrm{cm})_{\text {; }}$ CL: carapace length of trapped shrimp $(\mathrm{cm})_{i}$ -: no data available or not applicable

\begin{tabular}{|c|c|c|c|c|c|c|c|c|c|c|}
\hline Cast & $\mathrm{NO}$ & DO & $\mathrm{D}$ & DU & TD & $\mathrm{L}$ & A & V & $\mathrm{BL}$ & $\mathrm{CL}$ \\
\hline \multicolumn{11}{|c|}{ Frame 1} \\
\hline 1 & 1 & - & 1.1 & 13.0 & 30.0 & 86.0 & 297.2 & 81.7 & 3.0 & 1.3 \\
\hline 2 & 2 & 15.0 & 1.1 & 15.2 & 18.5 & 51.3 & 177.3 & 48.8 & 2.8 & 1.2 \\
\hline 3 & 2 & 9.5 & 1.0 & 10.5 & 23.2 & 55.1 & 173.1 & 43.3 & 3.2 & 1.2 \\
\hline 4 & 2 & 7.2 & 0.9 & .11 .0 & 26.0 & 35.0 & 99.0 & 22.3 & 2.0 & - \\
\hline 5 & 1 & - & 0.4 & - & 8.0 & 11.2 & 14.1 & 1.4 & - & - \\
\hline 6 & 2 & 11.0 & 1.1 & 12.5 & 24.5 & 48.0 & 165.9 & 45.6 & - & - \\
\hline 7 & 1 & - & 0.8 & - & 26.0 & 31.5 & . 79.2 & 15.8 & 2.5 & 1.2 \\
\hline 8 & 1 & í & 0.6 & - & 12.5 & 15.5 & 29.2 & 4.4 & - & - \\
\hline 9 & 1 & - & 0.9 & - & 16.0 & 26.8 & 75.8 & 17.1 & 2.0 & 1.1 \\
\hline 10 & 2 & 3.0 & 0.4 & 3.0 & 8.2 & 22.3 & 28.0 & 2.8 & - & - \\
\hline Total & & & & & & & 1138.8 & 283.2 & & \\
\hline \multicolumn{11}{|c|}{ Frame 2} \\
\hline 1 & 2 & 9.0 & 1.2 & 8.0 & 24.5 & 22.5 & 84.8 & 25.5 & 3.0 & 1.2 \\
\hline 2 & 2 & 7.0 & 1.0 & 8.0 & 25.5 & 64.0 & 201.1 & 50.3 & 3.5 & 1.3 \\
\hline 3 & 2 & 10.0 & 1.1 & 14.5 & 17.5 & 42.7 & 147.6 & 40.6 & - & - \\
\hline 4 & 2 & 8.5 & 1.2 & 6.0 & 21.5 & 41.9 & 158.0 & 47.4 & - & - \\
\hline 5 & 2 & 10.5 & 0.9 & 6.0 & 22.5 & 47.9 & 135.4 & 30.5 & 2.5 & 1.0 \\
\hline 6 & 2 & 3.5 & 0.9 & - & 23.0 & 43.5 & 123.0 & 27.7 & - & 1.2 \\
\hline Total & & & & & & & 849.9 & 222.0 & & \\
\hline \multicolumn{11}{|c|}{ Others $^{\mathbf{a}}$} \\
\hline 1 & 1 & - & 1.0 & - & 15.0 & 46.8 & 147.0 & 36.8 & 2.5 & 1.2 \\
\hline 2 & 1 & - & 1.1 & 11.5 & 21.0 & 56.4 & 194.9 & 53.6 & 3.0 & 1.2 \\
\hline 3 & 1 & - & 1.0 & 12.0 & 19.0 & 51.0 & 160.2 & 40.1 & 2.6 & 1.2 \\
\hline 4 & 2 & 11.0 & 1.3 & 5.0 & 20.5 & 40.8 & 166.6 & 54.2 & 3.3 & 1.1 \\
\hline
\end{tabular}

encased in resin, sex determinations could not be made (these shrimp do not possess pronounced sexual dimorphism).

Although 1 burrow was interconnected with 2 adjacent burrows (Fig. 2B), the corresponding casts each contained only 1 individual. The interconnections were tunnels with a diameter equal to that of the rest of the burrows. Such interconnections have been recorded in 2 previous instances for upogebiid burrows (Frey \& Howard 1975, Swinbanks \& Murray 1981); however, unlike those in the present study, most of the previously described interconnections had constricted apertural necks. Frey \& Howard (1975) postulated that the connections in the Upogebia affinis casts

Table 2. Upogebia spp. Comparison among burrows from 8 species. NO: number of surface openings; DU: depth of U-shaped tunnel $(\mathrm{cm})$; TD: total depth $(\mathrm{cm})$; A: burrow area $\left(\mathrm{cm}^{2}\right)$; V: burrow volume $\left(\mathrm{cm}^{3}\right)$

\begin{tabular}{|c|c|c|c|c|c|}
\hline Species & NO & DU & $\mathrm{TD}^{\circ}$ & A & $\mathrm{V}$ \\
\hline$U$. pugettensis ${ }^{a, b}$ & $2-4$ & $20-30$ & 60 & & \\
\hline$U$. affinis ${ }^{c, d}$ & $1-8$ & & 50 & & \\
\hline$U . p_{\text {pusilla }}^{\mathrm{e}, \mathrm{f}}$ & $2-4$ & $3-44$ & 150 & $4.8-1080$ & $0.3-535$ \\
\hline U. acanthura ${ }^{g}$ & 2 & & & & \\
\hline$U$. noronhensis $^{\mathrm{h}, \mathrm{i}}$ & $1-2$ & & 18 & & \\
\hline U. stellata ${ }^{\mathrm{i}, \mathrm{k}}$ & $2-3$ & $7-20$ & $22-26.5$ & $444-461$ & $86-103$ \\
\hline$U$. deltaura $^{\mathrm{k}}$ & $2-3$ & $15-24$ & 28 & & \\
\hline U. omissa ${ }^{1}$ & $1-2$ & $3-15$ & 30 & $14.1-297.2$ & $1.4-81.7$ \\
\hline
\end{tabular}


might have been junctions between mother and juvenile burrows, since many of the connected burrows were much smaller. This did not appear to be the case for $U$. omissa, since the connecting burrows were of the same diameter and of similar total size as the main tunnel: possibly they were temporary rather than permanent, since they were not a common feature of casts. They could be related to the breeding behavior of these shrimp, which is still unknown.

The body length of the trapped shrimp ranged from 2.0 to $3.5 \mathrm{~cm}$, so presumably they were adults; their carapace lengths were less variable, ranging from 1.0 to $1.3 \mathrm{~cm}$. Such variation in body length despite similar carapace length is typical for large specimens of Upogebia omissa (V.R.C. unpubl. obs.). Similar to other species of Upogebia (Dworschak 1983, Astall et al. 1997), the carapace length of the shrimp in the present study was larger than burrow diameter, except for 1 specimen, whose carapace length equalled burrow diameter. However, the widths of the burrow chambers were greater than the carapace lengths.

As body and carapace lengths of thalassinideans are often correlated with burrow diameter (Dworschak 1983, Rodrigues 1983, Rodrigues et al. 1984, Candisani 1994, Rowden \& Jones 1995), we used linear regression analysis to test for relationships between shrimp size and various burrow dimensions. The body length of the trapped shrimp was positively associated with burrow diameter and area $(\mathrm{p}=0.017$ and 0.031 , respectively, Fig. 6). The association between burrow diameter and body length of the trapped shrimp was significant, but with a low correlation coefficient $\left(r^{2}=0.42\right)$ compared to that in other studies on the Thalassinidea (Dworschak 1983, Rodrigues 1983, Rodrigues et al. 1984, Candisani 1994, Rowden \& Jones 1995). Possibly the correlation would have been higher had a wider range of organism sizes been collected, but juveniles were scarce in our study. Alternatively, the weak association could result from the generalistic feeding mode of the shrimp, which might place fewer restrictions on burrow dimensions. Again, a greater range of shrimp sizes would be necessary for such assessment.
A

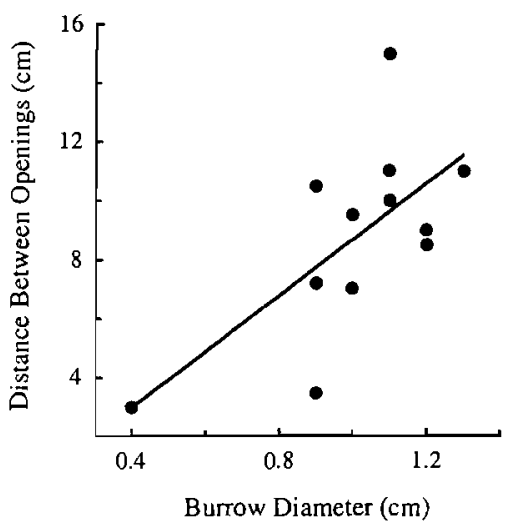

C

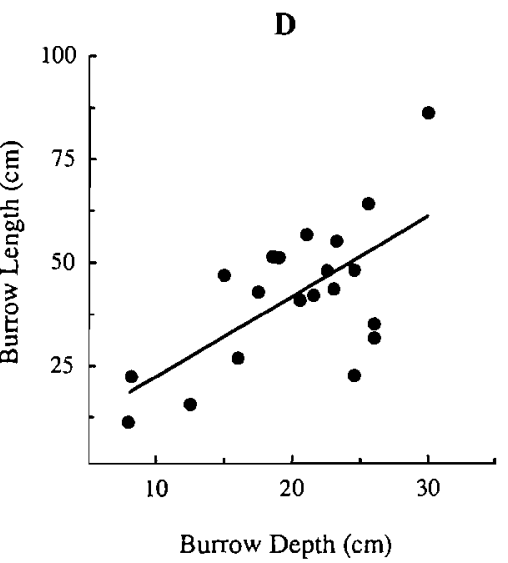

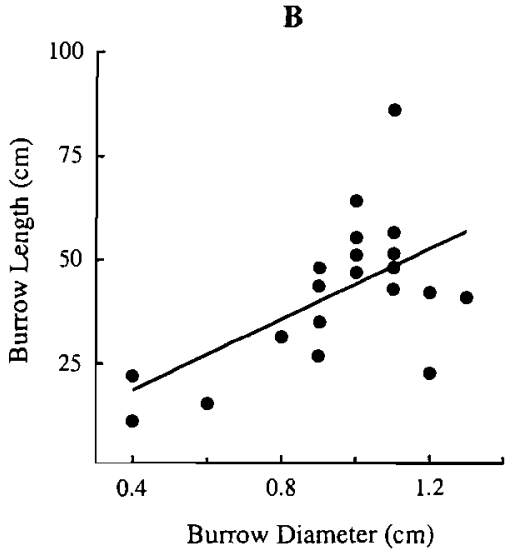

Fig. 5. Upogebia omissa. Relationship between burrow diameter and (A) distance between burrow openings $\left(y=9.51 x-0.82, p=0.018, r^{2}=0.44\right)$, (B) burrow length $\left(y=42.17 x+1.95, p=0.007, r^{2}=0.34\right)$, (C) burrow depth $(y=15.91 x+5.03, p=$ $\left.0.002, \mathrm{r}^{2}=0.43\right)$. (D) Relationship between burrow depth and length $(y=0.22 x+$ 10.97, $\mathrm{p}=0.002, \mathrm{r}^{2}=0.42$ ]

\section{Burrowing behavior}

Shrimp were placed into the modified aquarium containing sediment from the study site in order to observe burrowing behavior. Most individuals commenced digging immediately after introduction into the aquarium. They began burrowing into the substrate by collecting sediment with the dactyli of their 1st and 2nd pereiopods. This sediment was accumulated posteriorly in a basket-like structure formed by the setae of these appendages, and transported out of the burrow opening. The basket walls were formed by the 1st pereiopods, with the 2nd pereiopods comprising the basket floor. At the beginning of the excavation process, the shrimp would frequently move backwards, exiting the burrow to deposit the sediment. This action was repeated until a chamber 3 to $4 \mathrm{~cm}$ below the sediment surface was formed. Here, the shrimp changed direction, bending the abdomen over the cephalo- 
A

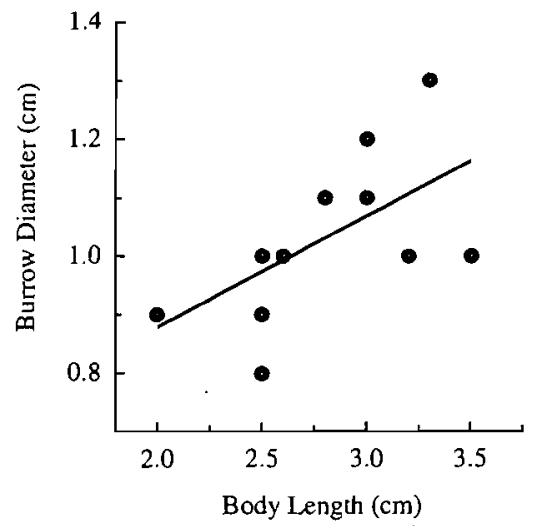

B

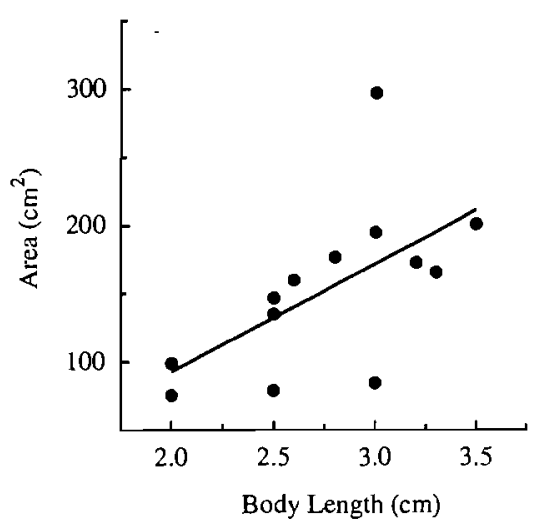

Fig. 6. Upogebia omissa. Relationship between shrimp body length and (A) burrow diameter $\left(y=2.20 x+0.51, p=0.017, \mathrm{r}^{2}=0.42\right)$, (B) burrow area $(y=0.005 x+2.07$, $\left.\mathrm{p}=0.031, \mathrm{r}^{2}=0.36\right)$

thorax in a 'somersault'. Following this maneuver, the shrimp was then able to deposit the sediment outside the burrow without having to expose its entire body. At the end of $24 \mathrm{~h}$, a complete burrow, typically with a Yformat, had been constructed.

The observed burrowing behavior of Upogebia omissa was similar to that described for $U$. pugettensis (MacGinitie 1930), but different from that of U. pusilla (Ott et al. 1976, Dworschak 1983). The latter species considerably enlarges its burrow by compressing the sediment against the burrow walls; $<50 \%$ of the sediment corresponding to the burrow volume is transported to the surface and ejected (Dworschak 1983). In the aquarium, $U$. omissa achieved most of its burrow volume (estimated visually) by transporting the sediment out of the opening, although during the initial digging phase some sediment compression did occur when the shrimp were lining their burrow walls.

Coarse fragments and shell pieces were usually deposited outside the burrow during the initial excavation process. Later, similar fragments were stored in burrow chambers or tunnel ends, as observed in the resin casts. Probably these large objects must be actively removed to enable careful lining of the burrow wall (Rodrigues \& Hödl 1990, Dworschak 1998) and to allow unobstructed movement inside the tunnels. Because such fragments are frequently too large to be expelled by the exhalant current engendered by the pleopods or to pass through the often constricted surface openings, they must be stored within the burrow itself (Rodrigues 1983, Suchanek 1983, Ziebis et al. 1996). The chambers and branches of Callianassidae burrows (Suchanek 1983, Tudhope \& Scoffin 1984, Dworschak \& Ott 1993, Ziebis et al. 1996) commonly contain such gravel deposits, but these have not been recorded in burrows of upogebiids until now. The fact that many of the studied species of this family inhabit muddy areas (Frey \& Howard 1975, Dworschak 1983), where this type of sediment selection may be unnecessary, could account for this.

During excavation, the burrow walls were lined with a mixture of an adhesive secretion and fine sediment by the dactyli of the 1st and 2nd pereiopods, and occasionally by the 3rd pereiopods. Such secretions were probably produced by glands located in the pereiopods, as described for other thalassinideans (Dworschak 1998). To obtain the finer particles, the shrimp collected sediment from the tunnel floor or end, then resuspended it while keeping the 1st and 2nd pereiopods well separated to permit the larger, heavier particles to settle through. When the finer particles began to deposit, the shrimp clasped its pereiopods together, forming a setal net for retention. Subsequently, the 1st and 2nd pereiopod pairs were moved rapidly up and down in opposite directions, possibly in order to mix the particles with the mucus prior to lining the burrow wall. The shrimp continually extended and reduced the size of their burrows, building new turning chambers and closing others, especially during the first $3 \mathrm{mo}$ in the laboratory. Later, despite a fairly constant burrow shape, the vertical depth of oblique tunnels was frequently changed. The entire tunnel, including chambers, was shifted up or down by several millimeters, indicating continuous relocation of sediment.

While digging, the 3rd to 5 th pereiopods were used for locomotion. The 5th and occasionally the 4th pereiopods also groomed the gill chamber. Generally, the pereiopod of one side cleaned the gill chamber of the opposite side. At times, the pereiopod of the same side cleaned the edges of the gill chamber. The 5th pereiopod pair was also responsible for pleopod grooming. The beating of the last 4 pairs of pleopods generated water circulation inside the burrow. This movement was also used during rapid locomotion of the shrimp. Moults were either buried in some part of the burrow, such as a chamber or a tunnel end, or were discarded outside the burrow opening.

\section{Intraspecific behavior}

These shrimp are of solitary habit, as evidenced by a single individual trapped per burrow cast. In the 
aquarium, when multiple shrimp were housed together, they typically displayed aggressive intraspecific behavior, regardless of whether they were of the same or opposite sex. This appears to be common among all studied species of this family found in muddy or sandy substrates (Pearse 1945, Ott et al. 1976. Tunberg 1986). During burrow excavation, the following responses were recorded on the occasions when one burrow was accidentally interconnected with another: the shrimp filled in the contact area with sediment $_{i}$ one individual, usually the larger, tried to occupy the burrow of the opponent; when of similar size, the shrimp usually began to fight; one shrimp, normally the smaller, retreated from the site of interconnection. Filling in of the contact area was also observed for Upogebia pusilla by Ott et al. (1976). Because there is a paucity of information about how these shrimp respond when burrows are accidentally interconnected, we are unclear as to what factors induced the different behaviors. Perhaps responses are partially dependent on the diameter of the interconnected burrow, which would provide the shrimp with information regarding the size of the other individual. Studies on intraspecific behavior in conditions simulating the natural environment would be valuable in understanding how these organisms interact in densely populated areas.

\section{Feeding behavior}

In the aquarium, shrimp were observed both filtering particles and deposit-feeding. To filter-feed, they stretched the first 2 pairs of pereiopods toward the burrow opening while producing an incoming water flow by moving their pleopods. This behavior usually took place in the U-shaped portion of the burrow, several centimeters below the surface, past the narrow constricture of the burrow opening, or within the first chamber below the opening. Particles suspended in this water flow were retained in the setal basket of the 1st and 2nd pairs of pereiopods. The setae of the latter were cleaned by the setae of the 3rd pair of maxillipeds, which move the particles toward the mouth. Similar filter-feeding mechanisms have been reported for other species of Upogebiidae (MacGinitie 1930, Dworschak 1987b, Scott et al. 1988, Nickell \& Atkinson 1995).

When feeding on the sediment, the shrimp collected particles from a single chamber or tunnel wall with the dactyli of the 1st and 2nd pereiopods, accumulating them in the setal basket. The 3rd maxillipeds bore the particles from the basket toward the mouth. Alternatively, the shrimp suspended the sediment with the 1st and 2 nd pereiopods, retaining the finer particles in the setal basket as described above for burrowing behavior and then carried them toward the mouth with the aid of the 3rd maxillipeds. In an isolated instance, a shrimp was observed to collect sediment in one chamber and transport it to a 2nd chamber. The 1st and 2nd pereiopod pairs were then moved rapidly up and down in opposite directions, resulting in sediment-sifting, with the larger particles being retained in the basket and the finer ones deposited on the chamber floor. The larger particles were then deposited in a 3rd chamber. The shrimp then returned to the 2nd chamber to feed on the fine particles previously deposited. When deposit-feeding, Upogebia omissa was capable of selecting particles based on size, most commonly by resuspension. The separation of particles by size into different chambers demonstrated a level of complexity in sediment selection not recorded before in the Thalassinidea. Deposit-feeding was usually associated with the oblique tunnels of the burrows.

Although direct observations have not been recorded for Upogebia affinis (Pearse 1945, Frey \& Howard 1975) and $U$, pusilla (Ott et al. 1976), plant fragments found incorporated into burrow walls suggest gardening as a feeding strategy of these species. No plant fragments were found associated with the burrow-cast walls of $U$. omissa, nor was gardening observed in the aquaria. This is supported by the fact that seagrasses were not found in the vicinity of the studied population. Conversely, we cannot be sure the shrimp do not utilize this behavior, since suitable substrate was not provided during the laboratory studies.

Since the defining work of MacGinitie (1930), filterfeeding has been considered the main trophic mode in the Upogebiidae (Dworschak 1987b, Scott et al. 1988, Nickell \& Atkinson 1995). However, as the ability to use more than 1 feeding mode is known for some species (Dworschak 1987b, Nickell \& Atkinson 1995), investigators have recently questioned if the preferential feeding mechanism is resource-dependent (Nickell \& Atkinson 1995).

Species of this family spend a considerable amount of time generating water flow into the burrow by beating their pleopods, in a position which would also allow them to filter-feed (MacGinitie 1930, Dworschak 1987b, Nickel \& Atkinson 1995). Such observations may have led researchers to believe that upogebiids are primarily filter-feeders. Nonetheless, as the filtering behavior is closely related to the process of water renewal, it is difficult to distinguish if the stimulus to irrigate is respiratory or nutritional (Astall et al. 1997). The dual trophic behavior observed in Upogebia omissa has also been reported for $U$. pusilla (Dworschak 1987b) and $U$. stellata (Nickell \& Atkinson 1995), but only filter-feeding has been recorded for $U$. pugettensis (MacGinitie 1930), U. acanthura and Po- 
matogebia operculata (Scott et al. 1988). From observations in our study, we cannot conclude which trophic mode, filter- or deposit-feeding, is preferential for $U$. omissa.

\section{Functional morphology of the burrow architecture}

The morphology of thalassinidean burrows appears to be partially related to the feeding modes of the inhabitants. For example, Dworschak \& Rodrigues (1997) suggested wider burrow diameter to be associated with deposit-feeding, and a close match between shrimp size and burrow diameter to indicate suspension feeding, since the shrimp must fit tightly in its burrow to engender effective tunnel ventilation (Dworschak 1981, 1987b). In fact, as we observed with Upogebia omissa, burrow diameter may be so narrow that the shrimp can only change directions in enlarged chambers (Dworschak 1983, Astall et al. 1997). Dworschak \& Rodrigues' (1997) proposal, while broadly accurate, does not include the possibility of depositfeeding by those shrimp classified as filter-feeders based on narrow burrow diameter (Dworschak 1987b, Nickell \& Atkinson 1995). On the other hand, wide burrow diameter in relation to inhabitant size does suggest deposit-feeding as the trophic mode, and may exclude filter-feeding as a potential trophic mechanism because of the physical limitations of the burrow.

Feeding modes have also been associated with burrow dynamics. Deposit-feeders appeared to regularly modify their burrow format, a result of frequent digging in the substrate while searching for food (Dworschak 1987b, Griffis \& Suchanek 1991, Nickell \& Atkinson 1995). Relatively permanent structures such as upogebiid burrows should therefore indicate filterfeeding to be the main or exclusive trophic mode of their inhabitants (Dworschak 1987b, Griffis \& Suchanek 1991). Based on our findings, the latter conclusion should be reconsidered. In our aquarium studies, we observed that after the initial excavation phase, entire oblique tunnels, including chambers, were shifted up and down by several millimeters, while the overall format of the burrow remained relatively constant. Consequently, during this process, the sediment lining at least one of the burrow walls (superior or inferior, depending in which direction the burrow was being shifted) had to be removed. In other thalassinidean studies it has been demonstrated that the first millimeters of the burrow walls contained greater numbers of bacteria than the surrounding sediment (Branch \& Pringle 1987, Dobbs \& Guckert 1988). These. high levels of bacteria in burrow wall-linings may result from the use of mucus secretions during burrow construction and to the subsequent oxygenation of this substrate (Branch \& Pringle 1987, Dobbs \& Guckert 1988). Thus, it is possible that Upogebia omissa was using this potentially enriched sediment for feeding, and this could be considered a form of 'gardening'. We believe that these observations on $U$. omissa indicate a more significant role of deposit-feeding behavior than has previously been attributed to species of this family. However, it is possible that differences in the availability and types of food in the aquaria induced feeding patterns that did not reflect those in nature. Nonetheless, the present study does demonstrate the plasticity of feeding behavior in $U$. omissa.

Some investigators have presented models relating burrow architecture to feeding modes in thalassinidean shrimp. Griffis \& Suchanek (1991) proposed the first such model, based primarily on a literature review. From their model, the burrows of Upogebia omissa could be classified as Type 5: U- or Y-shaped burrows belonging to exclusively or mainly filter-/suspensionfeeders. However, based on our observations, classifying $U$. omissa as filter-/suspension-feeders solely on the high prevalence of Y-shaped burrows would be too narrow a description of the trophic habits of this, and perhaps other species of Upogebiidae. Nickell \& Atkinson (1995) proposed that different components of the burrow morphology should be analyzed individually in order to identify the possibility of multiple feeding modes. In the present study, the $U$. omissa casts had a total of 4 of the 12 burrow features listed in Nickell \& Atkinson's model: chambered burrows, oblique tunnels, U- or Y-shaped burrow construction and circular tunnel cross-sections. The first 2 features indicate deposit-feeding, the latter 2 suspensionfeeding. We observed both trophic modes in $U$. omissa, supporting the precept of Nickell \& Atkinson's model that burrow components should be analyzed independently. However, we believe that models should be used cautiously in determining trophic modes until more information on this subject is available.

Burrow architecture may be related not only to feeding mechanisms but to other aspects of the biology of these shrimp, including reproduction and protection. The function of many burrow features may be associated with more than 1 behavioral mechanism, for example vertical or oblique tunnels could be related not only to feeding but also to protection, as they are usually located deeper in the sediment. It is also possible that similar burrow features may have different species-specific functions. Because there is much more information available on burrow architecture than feeding biology, models are valuable in providing clues as to which trophic modes may be used by a given species. However, to determine precisely which feeding strategies are in fact employed, behavioral observations are essential. 
We have studied a poorly characterized, yet numerically abundant species of thalassinidean shrimp, Upogebia omissa. In the dense population studied, the majority of burrows displayed the typical Y-format characteristic of many species of Upogebiidae. Although, historically, upogebiids have been considered to be exclusively or preferentially filter-feeders, we found that $U$. omissa may also have a marked tendency to deposit-feed. We believe this species would be more appropriately classified as a generalist feeder rather than exclusively as a filter-feeder. Detailed behavioral studies of upogebiids may reveal greater flexibility in feeding modes than previously described. Such analyses may also reveal which types of stimuli determine the preferred feeding process. Additionally, it is important to determine if the 2 types of burrows, Y-shaped and single oblique tunnels, indicate different trophic strategies in a single population. The Y-shaped burrows could indicate a truly generalist feeder, the oblique tunnels a generalist with a preference for deposit-feeding.

Acknowledgements. We are grateful to Austin Williams for his comments on the manuscript and the staff of the Centro de Biologia Marinha (CEBIMAR) for their help during field work. V.R.C. was funded by CAPES.

\section{LITERATURE CITED}

Alves ES, Pezzuto PR (1998) Population dynamics of Pinnixa patagoniensis Rathbun, 1918 (Brachyura: Pinnotheridae) a symbiotic crab of Sergio mirim (Thalassinidea: Callianassidae) in Cassino Beach, southern Brazil. PSZN I: Mar Ecol 19:37-51

Astall CM, Taylor AC, Atkinson RJA (1997) Behavioural and physiological implications of a burrow-dwelling lifestyle for two species of upogebiid mud-shrimp (Crustacea: Thalassinidea). Estuar Coast Shelf Sci 44:155-168

Atkinson RJA, Nash RDM (1990) Some preliminary observations on the burrows of Callianassa subterranea (Montagu) (Decapoda: Thalassinidea) from the west coast of Scotland. J Nat Hist 24:403-413

Branch GM, Pringle A (1987) The impact of the sand prawn Callianassa kraussi Stebbing on sediment turnover and on bacteria, meiofauna, and benthic microflora. J Exp Mar Biol Ecol 107:219-235

Brenchley GA (1981) Disturbance and community structure: an experimental study of bioturbation in marine soft bottom comrnunities. J Mar Res 39:767-790

Bussers JC, Poulicek M, Diepvints J (1983) Description d'une suceuse a air comprimé économique et utilisable par un seul plongeur. Cah Biol Mar 23:215-217

Candisani LC (1994) Biologia de Upogebia noronhensis Fausto-Filho (Decapoda, Thalassinidea): morfologia das galerias e zonação. In: $2^{\circ}$ Simpósio de Iniciação Cientifíca. Universidade de São Paulo

Candisani LC, Sumida PYG, Pires-Vanin AMS (1994) Morfologia das galerias de Upogebia sp (Decapoda: Thalassinidea). In: XX Congresso Brasileiro de Zoologia. Sociedade Brasileira de Zoologia, Rio de Janeiro
Dobbs FC, Guckert GB (1988) Callianassa trilobata (Crustacea: Thalassinidea) influences abundance of meiofauna and biomass, composition, and physiologic state of microbial communities within its burrow. Mar Ecol Prog Ser 45: 69-79

Dworschak PC (1981) The pumping rates of the burrowing shrimp Upogebia pusilla (Petagna) (Decapoda: Thalassinidea). J Exp Mar Biol Ecol 52:25-35

Dworschak PC (1983) The biology of Upogebia pusilla (Petagna) (Decapoda, Thalassinidea). I. The burrows. PSZN I: Mar Ecol 4:19-43

Dworschak PC (1987a) The biology of Upogebia pusilla (Petagna) (Decapoda: Thalassinidea). II, Environments and zonation. PSZN I: Mar Ecol 8:337-358

Dworschak PC (1987b) Feeding behaviour of Upogebia pusilla and Callianassa tyrrhena (Crustacea, Decapoda, Thalassinidea). Invest Pesq 51:421-429

Dworschak PC (1998) The role of tegumental glands in burrow construction by two Mediterranean callianassid shrimp. Senkenberg Marit 28:143-149

Dworschak PC, Ott JA (1993) Decapod burrows in mangrovechannel and back-reef environments at the Atlantic Barrier Reef, Belize. Ichnos 2:277-290

Dworschak PC, Pervesler P (1988) Burrows of Callianassa bouvieri Nobili 1904 from Safaga (Egypt, Red Sea) with some remarks on the biology of the species. Senkenberg Marit 20:1-17

Dworschak PC, Rodrigues SA (1997) A modern analogue for the trace fossil Gyrolithes: burrows of the thalassinidean shrimp Axianassa australis. Lethaia 30:41-52

Frey RW, Howard JD (1975) Endobenthic adaptations of juvenile thalassinidean shrimp. Meddr Dansk Geol Foren (Bull Geol Soc Denmark) 24:284-297

Gomes Corrêa MM (1968) Sobre as espécies de Upogebia Leach do litoral brasileiro, com descrição de uma espécie nova (Decapoda, Callianassidae). Rev Bras Biol 28: $97-109$

Griffis RB, Chavez FL (1988) Effects of sediment type on burrows of Callianassa californiensis Dana and C. gigas Dana. J Exp Mar Biol Ecol 117:239-253

Griffis RB, Suchanek TH (1991) A model of burrow architecture and trophic modes in thalassinidean shrimp (Decapoda: Thalassinidea). Mar Ecol Prog Ser 79:171-183

Hylleberg J (1975) Selective feeding by Abarenicola pacifica with notes on Abarenicola vagabunda and a concept of gardening in lugworms. Ophelia 14:113-137

Kihara TC, Rocha CEF (1993) Two new species of Hemicyclops (Copepoda: Poecilostomatoida: Clausidiiae) associated with mud shrimps of the genus Callichirus from Brazil. Bijdr Dierk 63:243-254

Lemaitre R, Rodrigues SA (1991) Lepidophthalmus sinuensis: a new species of ghost shrimp (Decapoda: Thalassinidea: Callianassidae) of importance to the commercial culture of penaeid shrimp on the Caribbean Coast of Colombia, with observations on its ecology. Fish Bull US 89:623-630

MacGinitie GE (1930) The natural history of mud shrimp Upogebia pugettensis (Dana). Ann Mag Nat Hist 10(6): $36-47$

MacGinitie GE (1934) The natural history of Callianassa californiensis (Dana). Am Midl Nat 15:166-177

Nash RDM, Chapman CJ, Atkinson RJA, Morgan PJ (1984) Observations on the burrows and burrowing behaviour of Calocaris macandreae (Crustacea: Decapoda: Thalassinoidea). J Zool 202:425-439

Nickell LA, Atkinson RJA (1995) Functional morphology of burrows and trophic modes of three thalassinidean shrimp species, and a new approach to the classification of tha- 
lassinidean burrow morphology. Mar Ecol Prog Ser 128: 181-197

Ott JA, Fuchs B, Fuchs R, Malasek A (1976) Observations on the biology of Callianassa stebbingi Borradaile and Upogebia litoralis Risso and their effect upon sediment. Senckenberg Marit 8:61-79

Pearse AS (1945) Ecology of Upogebia affinis (Say). Ecology 26:303-305

Pemberton GS, Risk MJ, Buckley DE (1976) Supershrimp: deep bioturbation in the Strait of Canso, Nova Scotia. Science 192:790-791

Phillips JP (1971) Observations on the biology of mud shrimps of the genus Callianassa (Anomura: Thalassinidea) in Mississippi Sound. Gulf Res Rep 3:165-196

Posey MH (1986) Changes in a benthic community associated with dense beds of a burrowing deposit feeder, Callianassa californiensis. Mar Ecol Prog Ser 31:15-22

Posey MH, Dumbauld BR, Armstrong DA (1991) Effects of a burrowing mud shrimp, Upogebia pugettensis (Dana), on abundances of macro-infauna. J Exp Mar Biol Ecol 148: 283-294

Rodrigues SA (1966) Estudos sobre Callianassa. PhD thesis, Universidade de São Paulo

Rodrigues SA (1983) Aspectos da biologia de Thalassinidea do Atlântico tropical americano. Livre Docência, Universidade de São Paulo

Rodrigues SA, Hödl W (1990) Burrowing behaviour of Callichirus major and $C$. mirim. Wiss Film 41:48-58

Rodrigues SA, Rocha RM (1993) Littoral compound ascidians (Tunicata) from São Sebastião, Estado de São Paulo, Brazil. Proc Biol Soc Wash 106:728-739

Rodrigues SA, Suguio K, Shimizu GY (1984) Ecologia e paleoecologia de Callichirus major Say (1818) (Crustacea,

Editorial responsibility: Gareth Harding (Contributing

Editor), Dartmouth, Nova Scotia, Canada
Decapoda, Thalassinidea). An Sem Reg Ecol 4:499-519

Rowden AA, Jones MB (1995) The burrow structure of the mud shrimp Callianassa subterranea (Decapoda: Thalassinidea) from the North Sea. J Nat Hist 29:1155-1165

Scott PJB, Reiswig HM, Marcotte BM (1988) Ecology, functional morphology, behaviour, and feeding in coral and sponge-boring species of Upogebia (Crustacea: Decapoda: Thalassinidea). Can J Zool 66:483-495

Shinn EA (1968) Burrowing in recent lime sediments of Florida and Bahamas. J Paleontol 42:879-894

Suchanek TH (1983) Control of seagrass communities and sediment distribution by Callianassa (Crustacea, Thalassinidea) bioturbation. J Mar Res 41:281-298

Swinbanks DD, Luternauer JL (1987) Burrow distribution of thalassinidean shrimp on a Fraser Delta tidal flat, British Columbia. J Paleontol 61:315-332

Swinbanks DD, Murray JW (1981) Biosedimentological zonation of Boundary Bay tidal flats, Fraser River Delta, British Columbia. Sedimentology 28:201-237

Tudhope AW, Scoffin TP (1984) The effects of Callianassa bioturbation on the preservation of carbonate grains in Davies Reef Lagoon, Great Barrier Reef, Australia. J Sedim Petrol 54:1091-1096

Tunberg B (1986) Studies on the population ecology of Upogebia deltaura (Leach) (Crustacea, Thalassinidea). Estuar Coast Shelf Sci 22:753-765

Williams AB (1993) Mud shrimps, Upogebiidae, from the Western Atlantic (Crustacea: Decapoda: Thalassinidea). Smithson Contr Zool 544:1-77

Ziebis W, Forster S, Huettel M, Jørgensen BB (1996) Complex burrows of the mud shrimp Callianassa truncata and their geochemical impact in the sea bed. Nature 382: 619-622

Submitted: March 10, 1999; Accepted: December 15, 1999

Proofs received from author(s): June 26, 2000 